\title{
Linking ocean biogeochemical cycles and ecosystem structure and function: results of the complex SWAMCO-4 model
}

\author{
Bénédicte Pasquer $^{\mathrm{a}}$, Goulven Laruelle ${ }^{\mathrm{a}, \mathrm{b}}$, Sylvie Becquevort ${ }^{\mathrm{a}}$, Véronique Schoemann ${ }^{\mathrm{a}}$, \\ Hugues Goosse ${ }^{\mathrm{c}}$, Christiane Lancelot ${ }^{\mathrm{a}, *}$ \\ ${ }^{a}$ Ecologie des Systèmes Aquatiques, Université Libre de Bruxelles, CP-221, Bd du Triomphe, B-1050, Bruxelles, Belgium \\ ${ }^{\mathrm{b}}$ Department of Earth Sciences, Geochemistry, Utrecht University, The Netherlands \\ 'Institut d'Astronomie et de Géophysique Georges Lemaître, Université Catholique de Louvain, Belgium
}

Received 1 April 2004; accepted 15 July 2004

Available online 23 November 2004

\begin{abstract}
We present results obtained with SWAMCO-4, a complex model of the marine planktonic system calculating $\mathrm{C}, \mathrm{N}, \mathrm{P}, \mathrm{Si}, \mathrm{Fe}$ cycling within the upper ocean, the export production and the exchange of $\mathrm{CO}_{2}$ between the ocean and atmosphere. The model, constrained by physical, chemical and biological (grazing, lysis) controls, explicitly details the dynamics of four relevant phytoplankton functional groups with respect to $\mathrm{C}, \mathrm{N}, \mathrm{P}, \mathrm{Si}, \mathrm{Fe}$ cycling and climate change. Those are diatoms, pico/nano phytoplankton, coccolithophorids, and Phaeocystis spp. whose growth regulation by light, temperature and nutrients has been obtained based on a comprehensive analysis of literature reviews on these taxonomic groups. The performance of SWAMCO-4 is first evaluated in a 1D physical frame throughout its cross application in provinces with contrasted key species dominance, export production, $\mathrm{CO}_{2}$ air-sea fluxes and where biogeochemical time-series data are available for model initialisation and comparison of results. These are: (i) the ice-free Southern Ocean Time Series station KERFIX $\left(50^{\circ} 40 \mathrm{~S}, 68^{\circ} \mathrm{E}\right)$ for the period 1993-1994 (diatom-dominated); (ii) the sea-ice associated Ross Sea domain (Station S; $76^{\circ} \mathrm{S}, 180^{\circ} \mathrm{W}$ ) of the Antarctic Environment and Southern Ocean Process Study AESOPS in 1996-1997 (Phaeocystis-dominated); and (iii) the North Atlantic Bloom Experiment NABE $\left(60^{\circ} \mathrm{N}, 20^{\circ} \mathrm{W}\right)$ in 1991 (coccolithophorids). We then explore and compare the ocean response to increased atmospheric $\mathrm{CO}_{2}$ by running SWAMCO-4 at the different locations over the last decade. Results show that at all tested latitudes the prescribed increase of atmospheric $\mathrm{CO}_{2}$ enhances the carbon uptake by the ocean. However, the amplitude of the predicted atmospheric $\mathrm{CO}_{2}$ sinks displays large regional and interannual variations due to the actual meteorological forcing that drives the local hydrodynamics. This is particularly true in the marginal ice zone of the Ross Sea (AESOPS) where the magnitude of the predicted annual $\mathrm{CO}_{2}$ sink is positively related to the length of the surface ocean ice-cover period which determines the iron surface concentration at the time of ice melting.
\end{abstract}

(C) 2004 Elsevier B.V. All rights reserved.

Keywords: Ecological modelling; Diatoms; Pico/nanophytoplankton; Coccolithophorids; Phaeocystis spp.; Iron; Air-sea $\mathrm{CO}_{2}$ fluxes; Global ocean; Antarctic Ocean; North Atlantic

* Corresponding author.

E-mail address: lancelot@ulb.ac.be (C. Lancelot).

1385-1101/\$ - see front matter (C) 2004 Elsevier B.V. All rights reserved.

doi:10.1016/j.seares.2004.07.001 


\section{Introduction}

Plankton ecosystems in oceanic surface waters are responsible for the export of biogenic carbon (C) and associated elements $(\mathrm{N}, \mathrm{P}, \mathrm{Si}, \mathrm{Fe})$ into the intermediate and deep waters of the oceans. Dissolved $\mathrm{CO}_{2}$ in surface waters is taken up by photosynthesising algae which require nutrients (phosphate, ammonium/ nitrate, and dissolved silica) and trace elements such as iron for their growth. Depending on the phytoplankton community and the associated food-web structure, the organic carbon produced is either retained in the surface layer through fast microbial respiration or exported to the deep ocean as phytoplankton cells, plankton detritus or zooplankton faecal pellets. In the latter case, a larger fraction of the carbon is retained by the ocean and less returns to the atmosphere. This flux of carbon to the deep ocean is called the biological carbon pump. Its efficiency relies, on the one hand, on light and nutrient controls of phytoplankton and ecosystem structures, and, on the other hand, on the mineralisation rate of exported carbon when sinking from the surface layer towards the deep ocean and finally buried in the sediment.

At this stage, a decade after the pioneering work of Martin (1990), there seems to be little doubt that iron plays a pivotal role in ecosystem structure and export production. Some $40 \%$ of the oceans are Fe-limited (HNLC regions) and all iron-enrichment experiments conducted in the HNLC waters of the Southern Ocean, both shipboard (e.g. Martin et al., 1990; Buma et al., 1991) and in situ (Boyd and Abraham, 2001; Landry et al., 2002) resulted in the stimulation of the large class of algae, in particular chain-forming diatoms (De Baar and Boyd, 1999). Accordingly, records in naturally iron-enriched regions of the Southern Ocean report biomass accumulation of chain-forming diatoms (De Baar et al., 1995) but also, in some regions, large gelatinous colonies of the non-siliceous Haptophyceae Phaeocystis (Arrigo et al., 2000; Lancelot et al., 1998). There now emerges a concept of a background plankton ecosystem of generally very small pico/nano phytoplankton which is mostly recycling the available chemical elements $(\mathrm{C}, \mathrm{N}, \mathrm{P}, \mathrm{Fe})$ within the euphotic zone, a retention system (Lancelot et al., 2000). For nitrogen (N) the major chemical form then is reduced ammonia, which is easily utilised by the cell, as opposed to nitrate, which must be reduced by the iron-rich enzymes nitrate- and nitrite reductase. When growth conditions including light, major $(\mathrm{N}, \mathrm{P}, \mathrm{Si})$ and trace $(\mathrm{Fe})$ nutrients are more favourable, intense blooms of generally larger-sized phytoplankton cells are able to use nitrate as the primary $\mathrm{N}$ source, a system resulting in new production. At such times, four taxonomic groups such as diatoms, Phaeocystis spp., coccolithophorids (notably Emiliania huxleyi) and $\mathrm{N}_{2}$-fixing diazotrophs, each in their own manner, are deemed to account for most of the overall biological pump in the oceans. These taxonomic groups are not blooming together but are found in contrasted biological provinces (Longhurst, 1998). Changes in phytoplankton dominance are accompanied by changes in the food web structure which have implications not only for the sequestration of $\mathrm{CO}_{2}$ into the deep ocean but also in supporting production at higher trophic levels, including species of major commercial fisheries, marine birds and mammals.

Diatoms alone account for about $1 / 3$ of annual primary production in the global ocean (e.g. Sarthou et al., 2005). Large diatoms usually sink out massively at the end of the bloom, when nutrient (notably $\mathrm{Fe}$ ) stress affects their buoyancy (e.g. Muggli et al., 1996). Phaeocystis spp. blooms have characteristic large-size (100-1000 micron) colonies composed of mucus-like polysaccharides, where at the end of the bloom coagulation and aggregation of mucus debris (where bacteria play a role) lead to the sinking of organic matter (e.g. Schoemann et al., 2005). Coccolithophorids such as E. huxleyi possess large amounts of inorganic-bound carbon as calcite. Towards the end of the blooms, many loose calcite coccoliths are being shed from its plant cell (Holligan et al., 1993), and the export of both organic matter and calcite coccoliths (as found in sediment traps, Fernandez et al., 1993) is largely within faecal pellets of mesozooplankton, a foodweb-driven export term. Finally in oligotrophic tropical and subtropical waters, diazotrophs such as the colony-forming Trichodesmium play a unique role in the global cycle of nitrogen due to their ability to fix atmospheric $\mathrm{N}_{2}$. The fate of Trichodesmium is generally that of nutrient cycling through the microbial loop (La Roche and Breitbarth, 2005) making nutrients available for other phytoplankton cells. Nitrogen fixation therefore provides a source of new nitrogen that enters from the atmosphere rather than 
from below and enhances the fixation of atmospheric $\mathrm{CO}_{2}$.

Estimating the role of the ocean in global carbon cycling and its response to or influence on climate change therefore needs a proper description of blooming phytoplankton species and the related trophic bifurcations, most notably the shift from the C-retaining microbial network towards the C-exporting linear food chain, under the multiple control of light, nutrients and biology such as grazing pressure and cell lysis. The most recent models of ocean carbon cycling set up to predict biotic responses to climate change (e.g. Aumont et al., 2002; Moore et al., 2002) include explicit or implicit description of these vital ecosystem processes. Yet some of these representations are very crude or empiric and lack mechanistic understanding.

As a first step to improve the mechanistic representation of ocean biogeochemical processes in global ocean models, we present results obtained with the complex ecological model SWAMCO-4. This model explicitly incorporates the processes directing the structure of the planktonic system composed of four taxonomic phytoplankton groups and their forcing functions. SWAMCO-4 results of the extension of ecosystem model SWAMCO (Sea WAter Microbial Community model; Lancelot et al., 2000) based on two taxonomic phytoplankton groups (diatoms and pico/nano phytoplankton), with two key phytoplankton taxons considered to be important players in the biogeochemical cycles in the different provinces of the world ocean and feedbacks to atmospheric $\mathrm{CO}_{2}$. These are the worldwide-distributed colony-forming Phaeocystis spp. and the calcifies coccolithophorids with Emiliana huxleyi as main representative. At this stage, Trichodesmium has not been incorporated yet. Beside the addition of state variables, numerical upgrade included the explicit description of calcium carbonate precipitation and dissolution as well as the implementation of the aggregation model of Kriest and Evans (2000). Upgraded parameterisation was derived from both literature reviews on these taxonomic groups (Sarthou et al., 2005; Schoemann et al., 2005; Veldhuis et al., 2005) as well as recently published literature (e.g. Paasche, 2002; Coale et al., 2003).

This paper briefly describes the SWAMCO-4 model and evaluates its coherence and performance in a $1 \mathrm{D}$ vertical physical frame throughout its cross application in oceanic provinces with contrasted key species dominance (Longhurst, 1998), export production (Schlitzer, 2002), $\mathrm{CO}_{2}$ air-sea fluxes (Takahashi et al., 2002) and where biogeochemical time-series data are available for model initialisation and results comparison. Additionally, SWAMCO-4 scenarios constrained with an increased annual atmospheric $\mathrm{CO}_{2}$ of $1.2 \mathrm{ppm}$ (Conway et al., 1994) are run at the different locations to explore and compare the ocean response to increased atmospheric $\mathrm{CO}_{2}$ over the last decade.

\section{Model description}

\subsection{General description of the SWAMCO-4 model}

The biogeochemical model is the complex SWAMCO model of Lancelot et al. (2000) modified as in Hannon et al. (2001) for consideration of air-sea $\mathrm{CO}_{2}$ exchanges and enlarged with an explicit description of coccolithophorids and Phaeocystis colony dynamics. Basically the ecological module of SWAMCO integrates knowledge on mechanisms controlling biological productivity and the structure of the ocean planktonic ecosystem. In particular, it takes into account the key role of iron in driving the structure and functioning of the planktonic network and the related biogeochemical cycles of C, N, Si, P, Fe. State variables (Fig. 1) include major nutrients $\left(\mathrm{NH}_{4}, \mathrm{NO}_{3}, \mathrm{DSi}, \mathrm{PO}_{4}\right)$ and dissolved iron (DFe). The phytoplankton assemblage is described by four groups [diatoms (DIA), pico/nano phytoplankton (NAN), coccolithophorids (CO) and Phaeocystis (OP)] distinguished on the basis of their physiology (iron and major nutrient uptake kinetics, photosynthetic parameters, sinking rate) and mode of biological (micro/ meso grazing, cell lysis) control.

Limitation of phytoplankton growth by irradiance and nutrients is expressed by the product of two Michaelis-Menten kinetics accounting for the availability of firstly the carbon substrates and energy and secondly the limiting nutrient. One single nutrient is considered to be limiting phytoplankton growth. It corresponds to the nutrient which displays the lowest ambient concentration compared to the half-saturation constant for phytoplankton uptake. Conceptually it 
<smiles>CC1(C)C2CCCC1CC2</smiles>

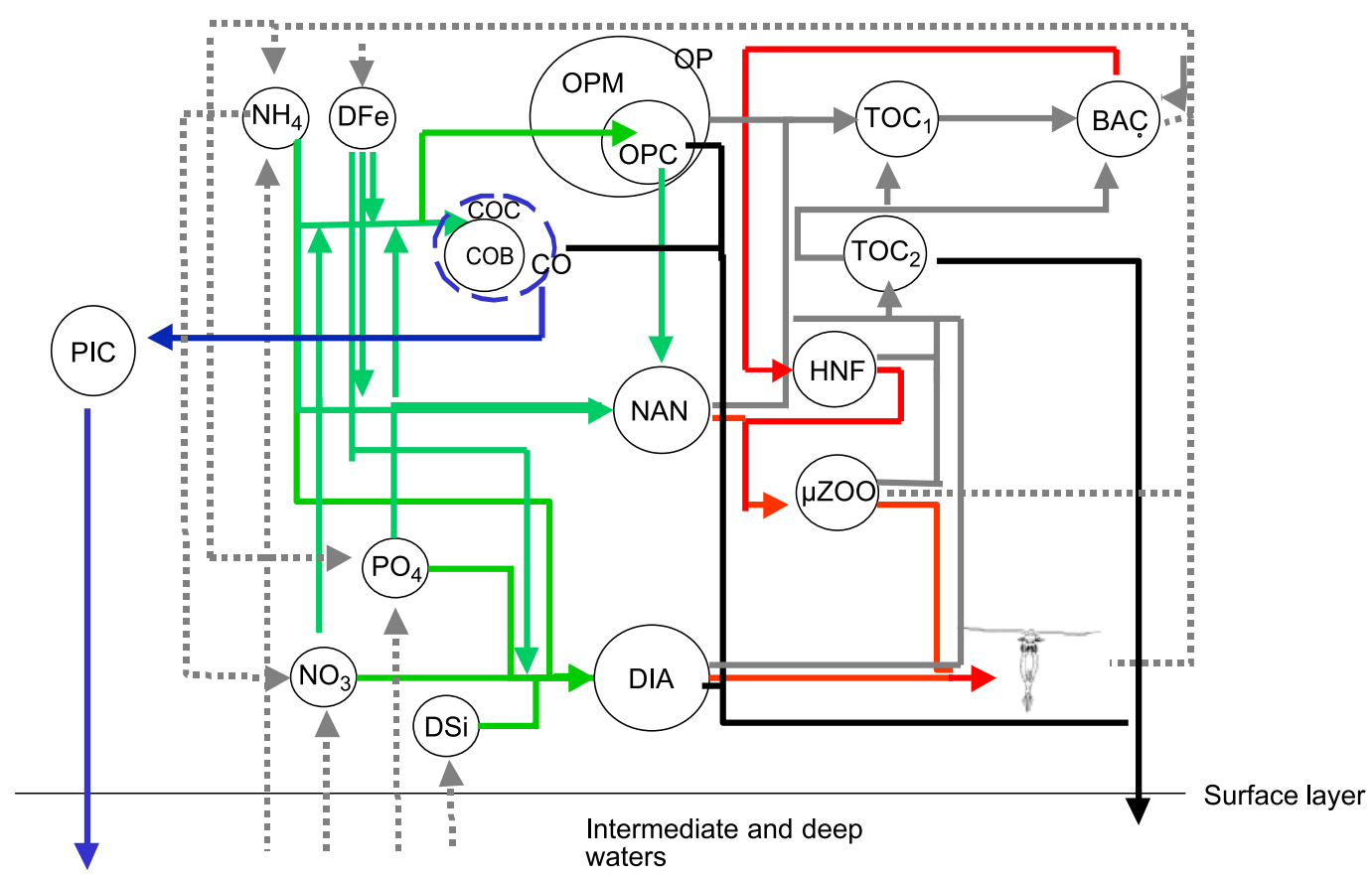

Fig. 1. Diagrammatic structure of the ecosystem model SWAMCO-4. Processes (arrows) and state variables. $\mathrm{NH}_{4}:$ ammonium; $\mathrm{NO}_{3}$ : nitrate; $\mathrm{PO}_{4}$ : phosphate; DSi: dissolved silica, DIA: diatom; NAN: nanophytoflagellate; OP, OPC, OPM: Phaeocystis colony, cell, colony polysaccharide matrix; $\mathrm{CO}, \mathrm{COB}, \mathrm{COC}$ : Coccolithophorid cell, biomass, attached coccoliths; $\mathrm{PIC}$ : $\mathrm{COC}+$ detached liths; $\mathrm{TOC}_{\mathrm{i}}$ : fast $(\mathrm{i}=1)$ and slowly $(\mathrm{i}=2$ ) biodegradable organic matter; BAC: bacteria; HNF: heterotrophic nanoflagellate; $\mu \mathrm{ZOO}$ : microzooplankton.

can be either inorganic $\mathrm{N}\left(\mathrm{NO}_{3}+\mathrm{NH}_{4}\right), \mathrm{DSi}, \mathrm{PO}_{4}$ or $\mathrm{Fe}$ and the selection is determined at each time step. Loss terms include sinking, grazing pressure and cell lysis. All cells are submitted to lysis, expressed as a temperature-dependent first order function of cell biomass. Diatoms, coccolithophorids cells and liths and disrupted senescent Phaeocystis colonies aggregate according to the model of Kriest and Evans (2000) and sink to deeper layers while, owing to their small size, pico/nano phytoplankton cells are retained in the surface layer. Coccolithophorids and pico/nano phytoplankton, the latter, however, with a preference rate, are ingested by microzooplankton whose growth processes and associated remineralisation rates are explicitly described. In contrast, mesozooplankton grazing constitutes a closure term of the model and is described as a first-order loss function for diatom and microzooplankton biomass (Hannon et al., 2001).
The microbial network includes organic matter with two classes of biodegradability, monomers, bacteria, auto- and hetero-trophic pico/nano plankton, coccolithophorids and microzooplankton.

Due to the short time scale studied, previous applications of SWAMCO on the ANT X/6 cruise (Lancelot et al., 2000) and SOIREE experiment (Hannon et al., 2001) neglected some processes of importance for simulation of annual cycles such as dissolution of biogenic silica (BSi) and nitrification. Based on Pondaven et al. (1998), a first-order kinetics has been chosen for parameterisation of the former process and the constant dissolution rate of $\mathrm{BSi}$ is set to $0.0005 \mathrm{~h}^{-1}$. Bacterial nitrification on the other hand, is described by a Michaelis-Menten equation characterised by a maximal nitrification rate of 0.006 $\mathrm{h}^{-1}$ (Bianchi et al., 1997). The equation also includes a term for considering the inhibition effect of light on 
the activity of nitrifying bacteria (Olson, 1981). Finally we revised the parameterisation of diatom and pico/nano phytoplankton iron physiology based on current knowledge and recent data (Sarthou et al., 2005; Veldhuis et al., 2005). This upgrading includes the addition of terms for describing iron limitation of photosynthesis and the updating of parameters describing the iron uptake kinetics and iron to carbon stoichiometry (Table 1). The iron control of photosynthesis was derived from Greene et al. (1991) and Schoemann (unpubl. data) and operates on optimal photosynthesis, photosynthetic efficiency and photoinhibition.

\subsection{Coccolithophorids module}

The module describes biomass production and calcification of coccolithophorids as well as the

Table 1

Taxon-specific parameters in SWAMCO-4

\begin{tabular}{|c|c|c|c|c|}
\hline Parameter & DIA & NAN & $\mathrm{CO}$ & OP \\
\hline \multicolumn{5}{|l|}{ Growth } \\
\hline Max gwth, $\mathrm{h}^{-1}$ & 0.06 & 0.06 & 0.065 & 0.06 \\
\hline Max photo, $\mathrm{h}^{-1}$ & 0.12 & 0.1 & 0.08 & 0.3 \\
\hline Optimal $\mathrm{T},{ }^{\circ} \mathrm{C}$ & $7.5 / 15$ & 16.3 & 20.9 & 16.3 \\
\hline$\Delta \mathrm{T},{ }^{\circ} \mathrm{C}$ & $5.3 / 12$ & 12.7 & 10.1 & 12.7 \\
\hline Ek, $\mu$ mole $\mathrm{m}^{-2} \mathrm{~s}^{-1}$ & 85 & 70 & 90 & variable \\
\hline Add. energy cost & no & no & calcification & no \\
\hline \multicolumn{5}{|c|}{ Nutrient uptake and stoichiometry } \\
\hline $\mathrm{K}_{\mathrm{N}}, \mu \mathrm{M}$ & 0.8 & 0.5 & 0.2 & 2 \\
\hline $\mathrm{K}_{\mathrm{P}}, \mathrm{nM}$ & 100 & 100 & 1 & 0.1 \\
\hline $\mathrm{K}_{\mathrm{Si}}, \mu \mathrm{M}$ & 0.4 & & & \\
\hline $\mathrm{K}_{\mathrm{Fe}}, \mathrm{nM}$ & $\begin{array}{l}\text { micro: } 0.7 \\
\text { nano:0.1 }\end{array}$ & 0.3 & 0.3 & 1.5 \\
\hline Fe:C, $\mu \mathrm{M}: \mathrm{M}$ & 80 & 50 & 30 & $\begin{array}{l}\text { cell:50 } \\
\text { mucus: } 80\end{array}$ \\
\hline $\mathrm{Si}: \mathrm{C}$ & Fe-dep. & & & \\
\hline $\mathrm{N}: \mathrm{P}$ & 16 & 16 & 16 & Cell:16 \\
\hline \multicolumn{5}{|l|}{ Losses } \\
\hline \multicolumn{5}{|l|}{ Grazing } \\
\hline Mesozoo & $\begin{array}{l}\text { Hannon } \\
\text { et al., } \\
2001\end{array}$ & no & no & no \\
\hline Microzoo & no & $\begin{array}{l}\text { Lancelot } \\
\text { et al., } \\
2000\end{array}$ & $\begin{array}{l}\text { Pasquer } \\
\text { et al., } \\
\text { submitted }\end{array}$ & $\begin{array}{l}\text { after col. } \\
\text { disruption }\end{array}$ \\
\hline Autolysis & \multicolumn{4}{|c|}{ Lancelot et al., 2000} \\
\hline Aggregation & yes & no & yes & $\begin{array}{l}\text { after col. } \\
\text { disruption }\end{array}$ \\
\hline
\end{tabular}

sinking export of calcium carbonate. It is described in detail in Pasquer et al. (submitted ms) and has been set up based on the literature review of E. huxleyi, the most widespread and studied coccolithophorids in the ocean (e.g. Paasche, 2002). Basically the coccolithophorid cell $\mathrm{CO}$ is described as composed of biomass (the coccosphere COB; Fig. 1) represented by two state variables (functional cellular and carbon monomers \& reserves; not shown) surrounded by coccoliths (external calcium carbonate plates; COC in Fig. 1) and a polysaccharide coating. The latter has been suggested crucial for coccolithogenesis (Van der Wal et al., 1983) and for speeding up the export of senescent cells by favouring aggregate formation (Engel et al., 2004). The module also includes one additional state variable for free liths (detached coccoliths) which are abundant at bloom decline (Balch et al., 1993). Main assumptions surrounding the coccolithophorids module parameterisation are briefly described below and the relevant parameters are reported in Table 1.

Calcification is a low cost energy process (Anning et al., 1996) and is not controlled by nutrients. The calcification process is accompanied by the production of exopolysaccharids (Van der Wal et al., 1983; Engel et al., 2004) parameterised as a constant coefficient of calcification arbitrarily set at 0.3 . There is a limited number of 20 coccoliths per cell biomass expressed as $0.5 * \mathrm{C}$-biomass. Above this number, coccoliths become detached from $\mathrm{CO}$ and are released as free liths in the surrounding seawater (PIC; Fig. 1). Biomass production is regulated by temperature, light and nutrients. Iron parameterisation is close to that of non-calcifying pico/nano phytoplankton NAN (Table 1). The half-saturation constant for $\mathrm{PO}_{4}$ uptake is set at a very low value $(1 \mathrm{nM})$ in order to consider the ability of $\mathrm{CO}$ to use organic phosphate as $\mathrm{P}$ source for their growth (Paasche, 2002). CO cells are grazed by microzooplankton ( $\mu$ ZOO; Fig. 1) but with a lower preference than naked nanophytoplankton cells after the hypothesis of Young (1994) that calcification is a mechanism for escaping grazing. This preference is expressed by attributing to $\mathrm{CO}$ micrograzing a higher half-saturation constant than to NAN. Autolysis releases dissolved and particulate organic matter as well as free liths (PIC) which are included in the aggregation process. Dissolution of free liths in the upper ocean is adjusted to $0.05 \mathrm{~d}^{-1}$ (Tyrrell and 
Taylor, 1996) in order to prevent their accumulation in the surface layer.

\subsection{Phaeocystis module}

The Phaeocystis module of Lancelot et al. (1997; submitted ms) set up for the iron-rich Southern Bight of the North Sea was further developed for application in iron-limited ocean provinces. Due to its complex life cycle (Rousseau et al., 1994), Phaeocystis is treated as two separate phytoplankton groups (Fig. 1) which correspond to the free-living single cell (NAN, Fig. 1) and colony life forms (OP; Fig. 1) each with a different trophic fate. An additional state variable stands for the mucus (mucilaginous matrix of the Phaeocystis colonies: OPM). This module has been calibrated in the Ross Sea (Pasquer et al., ms in prep.). Main assumptions surrounding model parameterisation (Table 1) can be summarised as follows.

Due to the polysaccharide nature of the colony matrix, the state variable set for mucus is expressed in carbon only but an additional parameterisation for mucus iron complexion is considered based on a mucus Fe:C stoichiometry of 80 ( $\mu \mathrm{M}: \mathrm{M}$; Schoemann et al., 2005). Iron associated to Phaeocystis mucus is considered to be an iron reservoir for Phaeocystis colony cells when ambient DFe is depleted. Ironmucus uptake by colony cells, however, ceases when $\mathrm{Fe}: \mathrm{C}$-mucus is arbitrarily equal to $50 \%$ of $\mathrm{Fe}: \mathrm{C}$ cell. However, information on iron parameterisation is limited (Schoemann et al., 2005). One unique Phaeocystis parameterisation has been set up for temperature-, light- and nutrient-growth dependence in the global ocean (Table 1; Fig. 2), based on the review by Schoemann et al. (2005) of the three main blooming species (P. pouchetii, P. globosa, P. antarctica). Healthy Phaeocystis colonies resist direct grazing by mesozooplankton. Lysis of senescent Phaeocystis colonies partly form aggregates and partly releases dissolved organic carbon available for bacterial growth and single Phaeocystis cells (NAN) which are actively grazed by microzooplankton ( $\mu$ ZOO, Fig. 1). Sinking is described by implementing the aggregation model (Kriest and Evans, 2000) after colony disruption (buoyant healthy colonies do not sink, see review by Passow, 2002 and Schoemann et al. 2005). Lysis of senescent colonies takes place when the ratio OPM:OPC is higher than a factor of two.

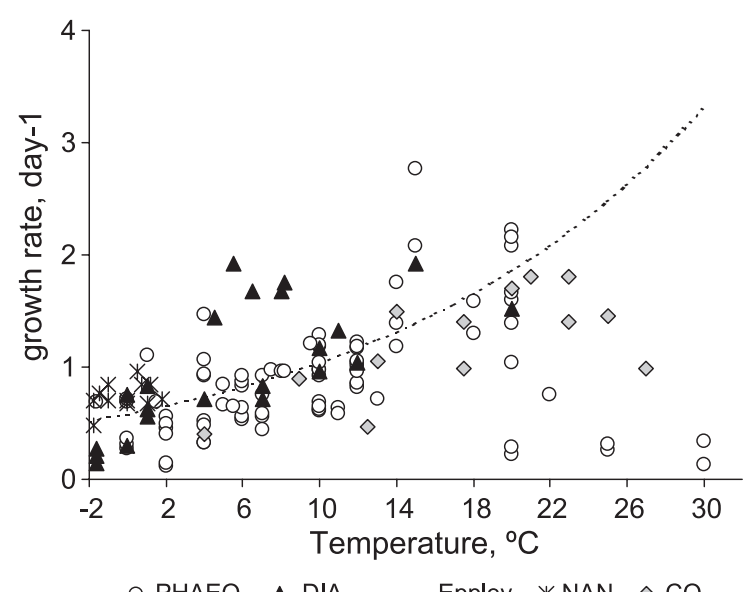

Fig. 2. Relationship between taxon-specific maximum phytoplankton growth rate and temperature as derived from literature review. Dashed line indicates the empirical formulation of Eppley (1972).

\subsection{Aggregation module}

Basically, the approach of Kriest and Evans (1999, 2000) to describing particle aggregation and sinking relies on an independent treatment of the particle number and biomass, each obeying its own conservation law. Average size and sinking rate of particles change as particles aggregate or the largest particles sink out. The size distribution of the aggregates is assumed to follow a hyperbolic law, whose exponent is a function of the average particle size. The relation between sinking speed and particle diameter is described by a power law. Equations and parameters are those described in Kriest and Evans $(1999,2000)$ except the carbon content coefficient, which is set at $1.6710^{5} \mathrm{nmol} \mathrm{cm}{ }^{-2.28}$ particle $^{-1}$ as in Jackson (1990). Essentially three parameters are determinant in this aggregation model: the average particle size (m), the stickiness factor (s) characterising the probability that two colliding particles will aggregate, and the probability that two dividing diatom cells will separate (p). These numbers were chosen site-specifically (Table 2).

\subsection{The one-dimensional physical model}

For all the applications described in this paper, the SWAMCO-4 biogeochemical model was coupled with a one-dimensional (1D) physical model of the sea ice and water column (Fig. 3). The 1D physical 
Table 2

Aggregation module: site-specific SWAMCO-4 parameters

\begin{tabular}{llll}
\hline JGOFS site & Cell size, $\mathrm{m}(\mathrm{cm})$ & Stickiness, $\mathrm{s}$ & Separation Prob., $\mathrm{p}$ \\
\hline NABE & 0.015 & 0.15 & 0.5 \\
KERFIX & 0.02 & 0.2 & 0.5 \\
AESOPS & 0.001 & 0.1 & 0.5 \\
\hline
\end{tabular}

model is derived from the 3D CLIO (Coupled Largescale Ice Ocean) model of Goosse et al. (2000), which is an Ocean General Circulation Model based on the usual assumptions, i.e., the hydrostatic equilibrium and the Boussinesq approximation. The representation of vertical mixing (Goosse et al., 1999) is based on a simplified version of the Mellor and Yamada level 2.5 model (Mellor and Yamada, 1982; Kantha and Clayson, 1994). The vertical viscosity and diffusivity are taken to be proportional to the characteristic velocity (q) and length (1) of turbulent motions and to stability functions calculated according to Kantha and Clayson (1994). q is derived from the differential equation governing the evolution of the turbulent kinetic energy while 1 is obtained from an algebraic function. The ocean component is coupled to the 3- layer thermodynamic sea ice model of Fichefet and Gaspar (1988), which is not activated at the KERFIX and NABE locations. Briefly, the thermodynamic seaice model simulates the changes of snow and ice thickness and the heat content in response to the surface and bottom heat fluxes. The variation of ice compactness due to thermal processes is determined after Häkkinen and Mellor (1990). The ice model also incorporates a parameterisation of the latent heat storage in brine pockets and a simple scheme for snow-ice formation.

\section{Model runs}

The performance of SWAMCO-4 was evaluated in the 1D vertical physical frame (Fig. 3) throughout its cross application at positions of time-series stations characterised by contrasted key species dominance (Longhurst, 1998), export production (Schlitzer, 2002), $\mathrm{CO}_{2}$ air-sea fluxes (Takahashi et al., 2002, revised in http://www.ldeo.columbia.edu/res/pi/CO2/) and where biogeochemical data are available for

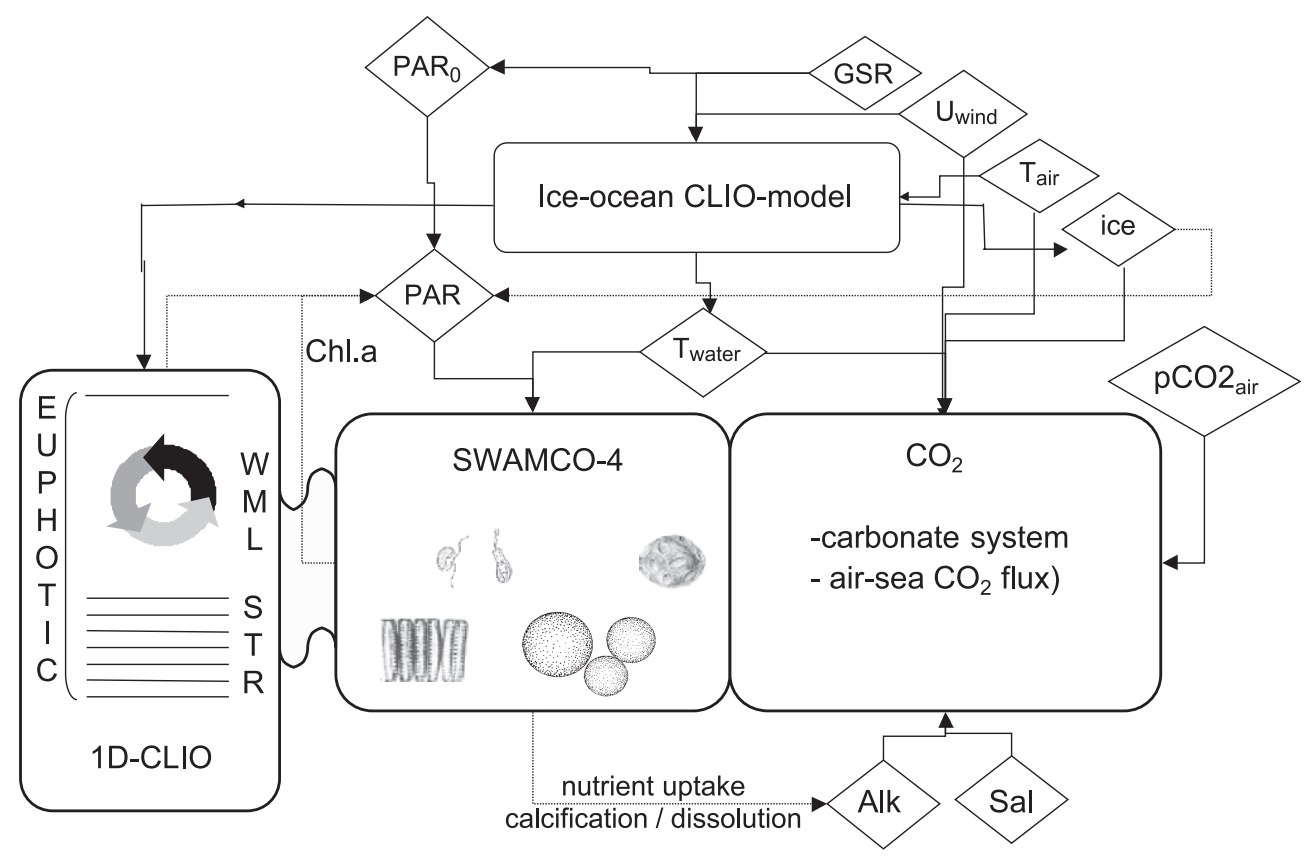

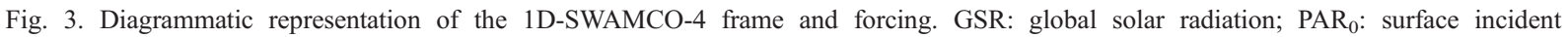
photosynthetically available radiation; PAR: photosynthetically available radiation in the water column; $\mathrm{U}_{\text {wind }}$ : wind speed; $\mathrm{T}_{\text {air }}$ : air temperature; $\mathrm{T}_{\text {water }}$ : water temperature; Alk: alkalinity; Sal: salinity. 
model initialisation and comparison of results. The following three JGOFS sites were chosen: the ice-free Southern Ocean Time Series station KERFIX $\left(50^{\circ} 40 \mathrm{~S}, 68^{\circ} \mathrm{E}\right)$ for the period $1993-1994$, the seaice associated Ross Sea domain (station S; $76^{\circ} \mathrm{S}$, $180^{\circ} \mathrm{W}$ ) of the Antarctic Environment and Southern Ocean Process Study AESOPS in 1996-1997, and the British North Atlantic Bloom Experiment NABE $\left(60^{\circ} \mathrm{N}, 20^{\circ} \mathrm{W}\right)$ in 1991.

In the standard configuration, vertical resolution is $1 \mathrm{~m}$ up to $100 \mathrm{~m}$. Below this depth the vertical step increases by $10 \%$ of the preceding value to the bottom of the ocean. The time step for 1D SWAMCO-4 is 30 $\min$. A restoring term on temperature and salinity with a restoring time scale of one year crudely parameterises the horizontal transport in the ocean. The 1D SWAMCO-4 model is dynamically driven by wind stress derived from the wind velocities, using a quadratic law. The surface fluxes of heat are determined from atmospheric data by using classical bulk formulas described in Goosse et al. (2000). Input fields consist of daily surface air temperatures and winds from the NCEP-NCAR re-analysis project for the period 1993-2002 (Kalnay et al., 1996) as well as climatological monthly surface relative humidities (Trenberth et al., 1989), cloud fractions (Berliand and Strokina, 1980), and precipitation rates (Xie and Arkin, 1996). Atmospheric input of bioreactive $\mathrm{Fe}$ is deduced from modelled fluxes reported by Lefevre and Watson (1999). For the Antarctic region in particular, a daily atmospheric input of bioreactive iron of 0.5 nmole $\mathrm{m}^{-2} \mathrm{~d}^{-1}$ (Lefevre and Watson, 1999) was assumed to be accumulated in the ice during Austral winter and released in the surface layer at the time of ice-melting.

For each area investigated, simulations were carried out up to year 2002 after a 4-y spin-up run with first-year conditions (NABE: 1991; KERFIX: 1993; AESOPS: 1996). Nutrients, DFe, dissolved inorganic carbon (DIC), and Chl-a initial winter conditions (Table 3) were retrieved from the JGOFS database (http://usjgofs.whoi.edu/jg/dir/jgofs/). When not measured DFe was extracted from the recently published compilation of iron data (De Baar and De Jong, 2001). Atmospheric $\mathrm{CO}_{2}$ concentration was set at $352 \mathrm{ppm}$ in 1991 and an annual increase of $1.2 \mathrm{ppm}$ was considered (Conway et al., 1994).

\section{Model performance}

\subsection{Phytoplankton bloom and taxon dominance}

Fig. 4 compares the annual simulation of DFe, total phytoplankton (Chl-a) and phytoplankton groups (DA, NAN, CO, OP) biomass obtained at NABE (Fig. 4a), KERFIX (Fig. 4b) and AESOPS (Fig. 4c) locations by cross application of 1D SWAMCO-4. As a general trend, SWAMCO-4 reproduces reasonably well the order of magnitude of observed springsummer maxima of phytoplankton biomass [NABE: $1.2 \mathrm{mg} \mathrm{Chl-a} \mathrm{m}{ }^{-3}$ (Holligan et al., 1993); KERFIX: 1 mg Chl-a m ${ }^{-3}$ (Fiala et al., 1998a); AESOPS: 5-10 mg Chl-a m ${ }^{-3}$ (Lancelot et al., 1998; Smith et al., 2003)]. The maximum Chl-a reached is positively linked to the maxima of winter DFe (Fig. 4, left panel). For the SWAMCO-4 application in the Ross Sea, the snow/ice accumulation over the Austral winter of iron from above was found crucial to explain the elevated surface concentration of DFe (up to $8 \mathrm{nM}$ ) often observed at the time of ice melting (Sedwick and Di Tullio, 1997). In our simulations this process is responsible for the sudden increase of DFe (from 0.2 to $10 \mu$ mole $\mathrm{m}^{-3}$ ) simulated by SWAMCO4 in November 1996 (Fig. 4c, left panel). Adding a daily atmospheric input of DFe had, however, no such positive effect on phytoplankton bloom simulations in the permanently ice-free location (KERFIX) due to the dilution of the atmospheric iron input within the upper mixed layer (not shown).

Model predictions of species succession are in good agreement with current knowledge of phyto-

Table 3

Winter initial conditions for the three different JGOFS test areas

\begin{tabular}{|c|c|c|c|c|c|c|c|}
\hline JGOFS site & $\mathrm{NO} 3 \mu \mathrm{mol} \mathrm{kg}{ }^{-1}$ & $\mathrm{Si}(\mathrm{OH})_{4} \mu \mathrm{mol} \mathrm{kg} \mathrm{kg}^{-1}$ & $\mathrm{PO}_{4} \mu \mathrm{mol} \mathrm{kg}{ }^{-1}$ & $\mathrm{DIC} \mu \mathrm{mol} \mathrm{kg}{ }^{-1}$ & ALK $\mu \mathrm{mol} \mathrm{kg} \mathrm{kg}^{-1}$ & $\mathrm{DFe} \mu \mathrm{mol} \mathrm{m} \mathrm{m}^{-3}$ & Chl-a mg m${ }^{-3}$ \\
\hline NABE & 10.5 & 7 & 0.65 & 2095 & 2341 & 0.6 & 0.2 \\
\hline KERFIX & 27.6 & 19.5 & 1.96 & 2140.5 & 2278 & 0.6 & 0.2 \\
\hline AESOPS & 30.2 & 77.7 & 2.17 & 2232 & 2342 & 0.3 & 0.15 \\
\hline
\end{tabular}


a : NABE

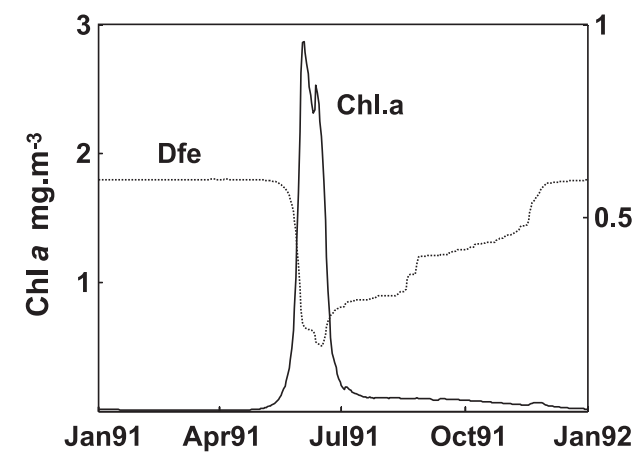

b : KERFIX

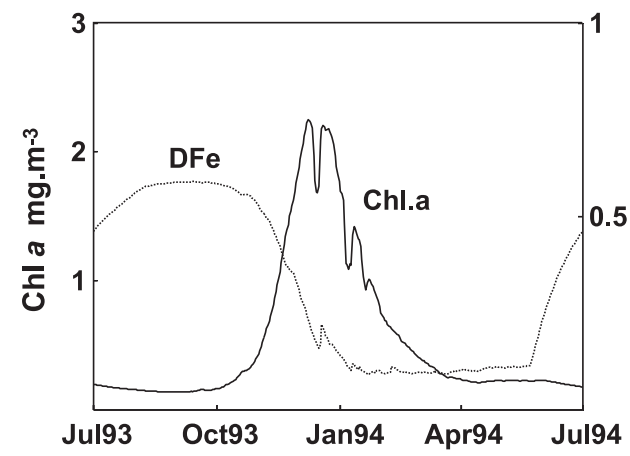

c : AESOPS

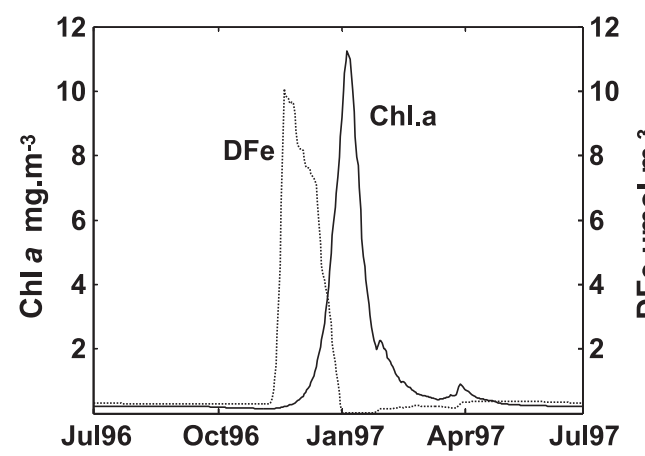

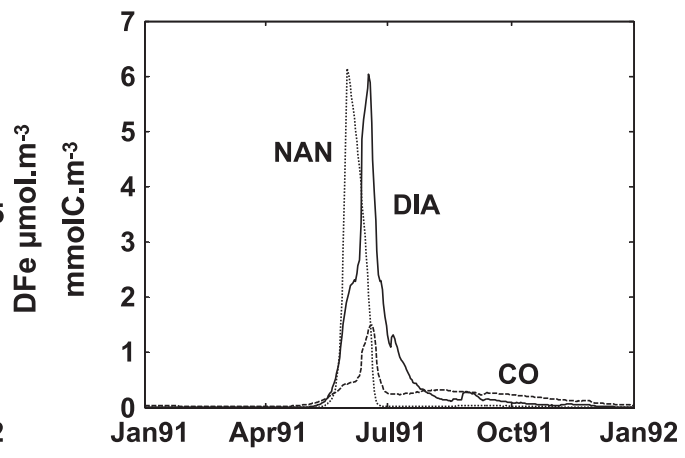
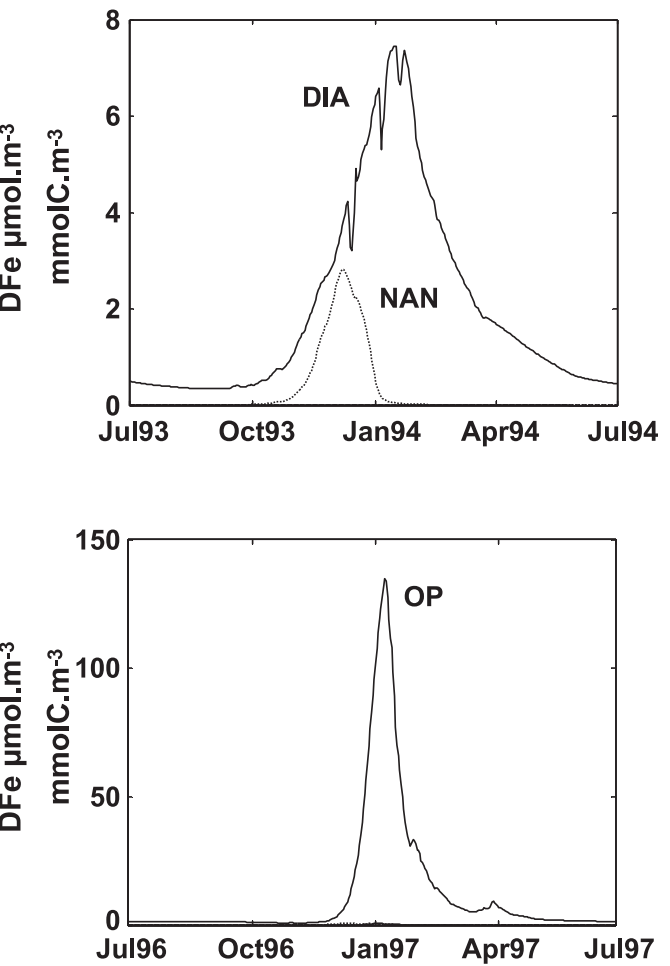

Fig. 4. SWAMCO-4 predictions of dissolved iron (DFe), total phytoplankton (Chl-a) and carbon biomass of phytoplankton groups (DIA: diatom; NAN: pico/nano phytoplankton; CO: coccolithophorids; OP: Phaeocystis colonies) at (a) NABE in 1991, (b) KERFIX in 1993-1994, and (c) AESOPS in 1996-1997.

plankton dominance at the three JGOFS sites. For instances model runs in the North Atlantic Ocean (NABE; Fig. 4a, right panel) generate a bloom of coccolithophorids but prevent blooming of Phaeocystis colonies (Fig. 4a, right panel). In particular, SWAMCO-4 reproduces well the reported E. huxleyi $\mathrm{C}$ biomass of $\sim 20 \mathrm{mg} \mathrm{C} \mathrm{m}^{-3}$ and cell density of $\sim 10^{6}$ cells $1^{-1}$ recorded in the NABE region (Fig. 4a, right panel; Holligan et al., 1993).

In the iron-limited Southern Ocean waters of KERFIX, SWAMCO-4 predicts in the austral summer modest blooms of diatoms and pico/nano phytoplankton with an absence of coccolithophorids and Phaeocystis colony blooms (Fig. 4b, right panel). Although 
Phaeocystis colony blooms were never reported at the latitude of KERFIX (Fiala et al., 1998b) there is some indication of the presence of low densities of coccolithophorid cells. Sensitivity tests (not shown) indicate that the unsuccessful development of $\mathrm{CO}$ in our current model is due to their incorporation with diatoms in the aggregation module. Optimal CO growth conditions are met at diatom decline i.e. when large diatom-derived aggregates are formed and drag CO cells to the deep ocean. Low CO density of $\sim 10^{4}$ cells $1^{-1}$ at KERFIX location can well be simulated when the only detached liths are assumed to aggregate and sink at the same rate as particulate organic matter $\left(0.1 \mathrm{~m} \mathrm{~h}^{-1}\right.$; Pasquer et al., submitted $\left.\mathrm{ms}\right)$.

Application of 1D SWAMCO-4 in the Ross Sea in 1996-1997 predicts the development of a massive Phaeocystis colony bloom (Fig. 4c, right panel). The maximal cell number $\left(10^{7}\right.$ cells $1^{-1}$, based on simulated maximal OPC and assuming a Phaeocystis cellular carbon content of $14 \mathrm{pg}$; Schoemann et al., 2005) fits existing records (Smith et al., 2003), both in timing and magnitude. Clearly in our simulations, the success of Phaeocystis colonies was explained by their ability to store DFe in the polysaccharidic matrix OPM, making DFe unavailable for the other three phytoplankton groups (DA, NAN, CO) even when some of these groups are more competitive with respect to their iron parameterisation (Table 1). Best fitting for diatom occurrence and the related consumption of biogenic silica could well be obtained when a second diatom group characterised by a low iron uptake constant of $0.1 \mathrm{nM}$ (e.g. pseudo-nitzschia; Coale et al., 2003) was considered (Pasquer et al., ms in prep.). Interestingly, the predicted iron demand of these diatoms was satisfied by iron from below after deepening of the mixing layer.

\subsection{Primary production, export production and air- sea $\mathrm{CO}_{2}$ fluxes}

An additional approach to evaluate the SWAMCO4 prediction capability is provided by estimations of carbon flow rates. Table 4 compares SWAMCO-4 predictions of primary production, carbon export production at $100 \mathrm{~m}$ and air-sea $\mathrm{CO}_{2}$ fluxes at the three JGOFS site locations with existing data. The predictions show reasonable agreement with other estimates based on field-true measurements and obtained by either inverse modelling of nutrient fields (Schlitzer, 2002) or statistical composite based on $\mathrm{CO}_{2}$ data (Takahashi et al., 2002, revised in http:// www.ldeo.columbia.edu/res/pi/CO2/). Predicted export production varies by a factor of two, being lowest at NABE in the North Atlantic $\left(10 \mathrm{gC} \mathrm{m}^{-2}\right.$ $\mathrm{y}^{-1}$; Table 4) and highest at AESOPS location (21 gC $\mathrm{m}^{-2} \mathrm{y}^{-1}$; Table 4). However, export production at the latter location represents a low (25\%) fraction of primary production in comparison with NABE $(36 \%)$ and KERFIX (55\%), giving support to the current assumption that Phaeocystis colony production contributes less to the vertical flux of particles to the deep ocean than to diatom production. Accordingly, at the diatom-dominated KERFIX station our model runs predict that as much as $55 \%$ of annual primary production is leaving the upper ocean.

On an annual mean, an atmospheric $\mathrm{CO}_{2}$ sink is predicted at the three test locations (Table 4). These predictions are in fairly good agreement with revised estimates by Takahashi et al. (2002) (see http:// www.ldeo.columbia.edu/res/pi/CO2; Table 4) for 1995. Comparison with SWAMCO-4 predictions obtained when biology is set at zero (Table 5) points out the significant contribution of biological processes

Table 4

SWAMCO predictions of annual primary production, carbon export production at $100 \mathrm{~m}$ and air-sea $\mathrm{CO}_{2}$ fluxes at three JGOFS site locations

\begin{tabular}{|c|c|c|c|c|c|c|}
\hline \multirow[t]{2}{*}{ JGOFS site } & \multirow[t]{2}{*}{ Coordinates } & \multirow{2}{*}{$\begin{array}{l}\text { Prim. Prod. } \mathrm{gC} \mathrm{m}^{-2} \mathrm{y}^{-1} \\
\text { SWAMCO-4 }\end{array}$} & \multicolumn{2}{|c|}{ Export $\mathrm{gC} \mathrm{m}^{-2} \mathrm{y}^{-1}$} & \multicolumn{2}{|c|}{ Air-sea $\mathrm{CO}_{2}$ mole $\mathrm{m}^{-2} \mathrm{y}^{-1}$} \\
\hline & & & SWAMCO-4 & Data $^{a}$ & SWAMCO-4 & Data $^{\mathrm{b}}$ \\
\hline NABE & $60^{\circ} \mathrm{N}, 20^{\circ} \mathrm{W}$ & 28 & 10 & & -4.2 & $-(4-5)$ \\
\hline KERFIX & $50^{\circ} 40 \mathrm{~S}, 68^{\circ} \mathrm{E}$ & 29 & 16 & $20-30$ & -0.37 & $-1-0$ \\
\hline AESOPS & $76^{\circ} \mathrm{S}, 180^{\circ} \mathrm{W}$ & 83 & 21 & 5 & -1.4 & $-2-0$ \\
\hline
\end{tabular}

Comparison with published estimates.

a Schlitzer, 2002.

b Takahashi et al., 2002 revised in http://www.ldeo.columbia.edu/res/pi/CO2/carbondioxide/pages/air_sea_flux_rev1.html. 
Table 5

SWAMCO predictions of air-sea $\mathrm{CO}_{2}$ fluxes at three JGOFS site locations: reference run and predictions obtained when biology is not operating

\begin{tabular}{llll}
\hline JGOFS & Coordinates & \multicolumn{2}{l}{ SWAMCO-4 Air-sea $\mathrm{CO}_{2}$ mole $\mathrm{m}^{-2} \mathrm{y}^{-1}$} \\
\cline { 3 - 4 } site & & reference & no biology \\
\hline NABE & $60^{\circ} \mathrm{N}, 20^{\circ} \mathrm{W}$ & -4.2 & -3.4 \\
KERFIX & $50^{\circ} 40 \mathrm{~S}, 68^{\circ} \mathrm{E}$ & -0.37 & +1.1 \\
AESOPS & $76^{\circ} \mathrm{S}, 180^{\circ} \mathrm{W}$ & -1.4 & +0.4 \\
\hline
\end{tabular}

in the Southern Ocean and especially in the marginal ice zone of the Ross Sea to the atmospheric $\mathrm{CO}_{2}$ sink. In the absence of biological activity, these two locations are predicted to act as a source rather than a sink for atmospheric $\mathrm{CO}_{2}$. The similar numerical experimentation conducted at the NABE site suggests that thermodynamic condition, winter DIC and alkalinity are driving $\mathrm{CO}_{2}$ exchange processes and are the principal factors responsible for the negative value (Table 5). Biological activity in turn enhances this primary effect by increasing the magnitude of the atmospheric $\mathrm{CO}_{2}$ sink (Table 5). Additional SWAMCO runs obtained when the coccolithophorid module is set at zero (not shown) suggest that when blooming these calcifiers are repressing the $\mathrm{CO}_{2}$ sink of the biological component.

\section{Forecasting of the ocean response to increased atmospheric $\mathrm{CO}_{2}$}

Despite the obvious limitations of the 1D representation of the water column, we performed longterm SWAMCO-4 runs to investigate the effects of changing atmospheric forcing (temperature, wind, global solar radiation, $\mathrm{pCO}_{2}$ ) over the last decade with particular attention paid to the impact of atmospheric $\mathrm{CO}_{2}$ increase. For this purpose we compared results obtained by running 1D SWAMCO-4 with prescribed increased atmospheric $\mathrm{pCO}_{2}$ and by maintaining atmospheric $\mathrm{pCO}_{2}$ at a constant value corresponding to the spin-up year for each test area. Results obtained at the three JGOFS sites were analysed in terms of interannual variability of phytoplankton blooms and species dominance (Fig. 5) and air-sea $\mathrm{CO}_{2}$ fluxes (Fig. 6). For the two ice-free locations (NABE, KERFIX) phytoplank- ton blooms showed little variability over the simulated period probably due to the simplified scheme of the physical structure which restores the winter stock of nutrients each year. In contrast, phytoplankton blooms in the marginal ice zone of the Ross Sea (AESOPS, Fig. 5c) displayed a remarkable interannual variability of about one order of magnitude. In our model this variability is related to the predicted duration of the ice cover period, which, together with physical conditions of ice melting, determines both the depth of the surface layer and the level of DFe available to phytoplankton at the time of ice melting. Clearly for DFe concentration lower than $2 \mu \mathrm{mol}$
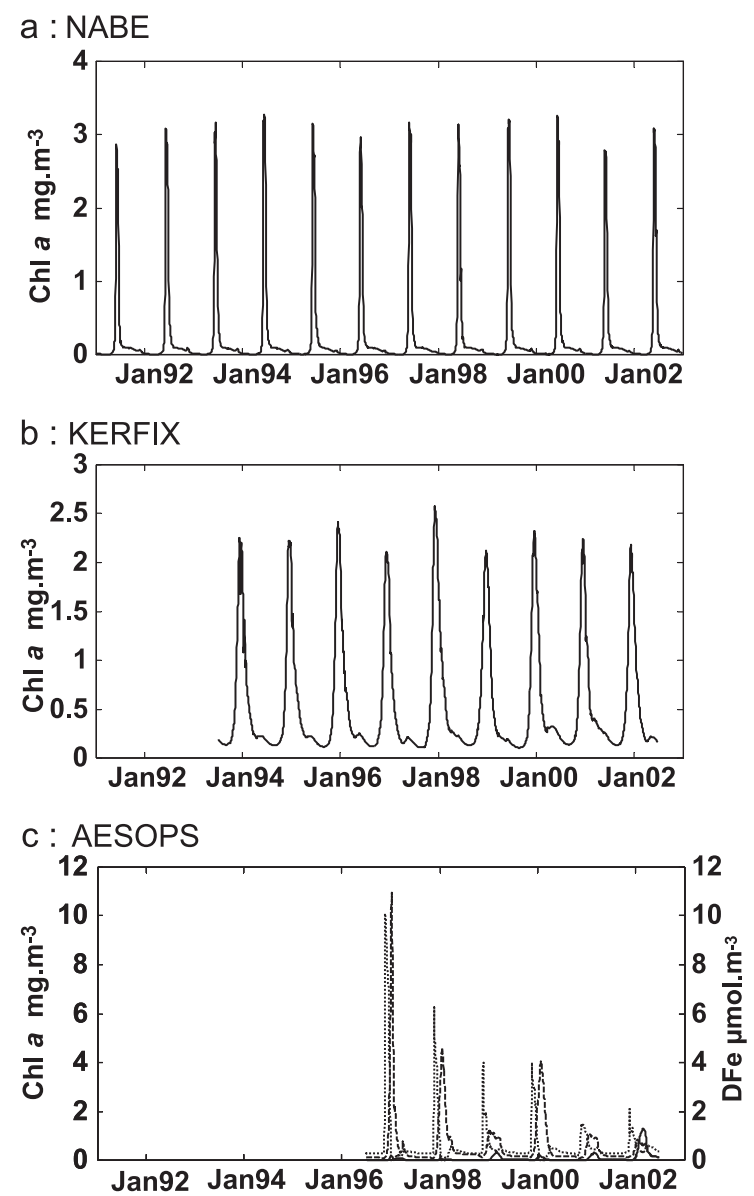

Fig. 5. Interannual SWAMCO-4 predictions of total phytoplankton biomass (Chl-a) from spin-up year up to 2002 at (a) NABE, (b) KERFIX, and (c) AESOPS for an annual increase atmospheric $\mathrm{CO}_{2}$ of $1.2 \mathrm{ppm}$. 

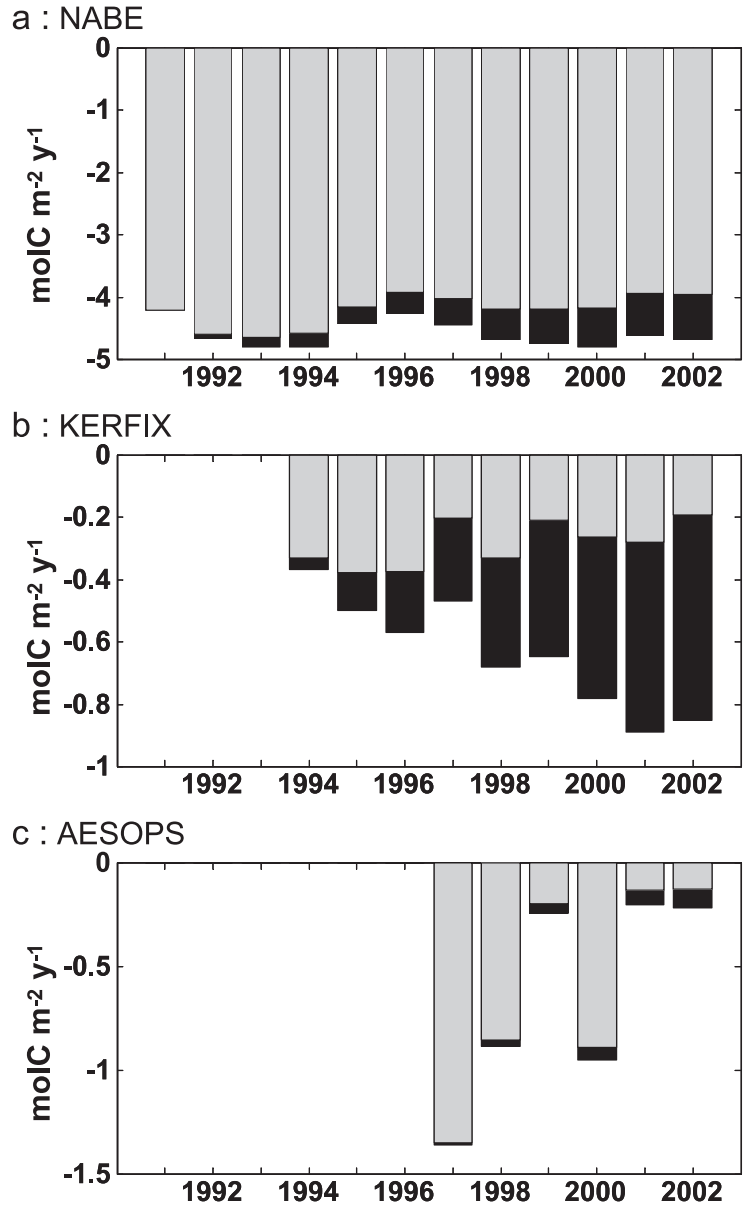

Fig. 6. Long-term SWAMCO-4 predictions of air-sea $\mathrm{CO}_{2}$ fluxes at (a) NABE, (b) KERFIX, and (c) AESOPS for increasing (total vertical blocks) and constant (grey vertical blocks) atmospheric $\mathrm{CO}_{2}$ corresponding to that of the spin-up year.

$\mathrm{m}^{-3}$, Phaeocystis colonies are not competitive and the spring phytoplankton bloom remains modest $\left(<2 \mathrm{mg} \mathrm{Chl-a} \mathrm{m} \mathrm{m}^{-3}\right.$; Fig. 5c) and dominated by diatoms (not shown).

For all simulated regions, the ocean responds positively to the $1.2 \mathrm{ppm}$ annual increase of atmospheric $\mathrm{CO}_{2}$ imposed on the model over the simulated period (Fig. 6) but the predicted interannual variability of the air-sea $\mathrm{CO}_{2}$ fluxes is regionally variable (Fig. 6).

At the NABE location, an average atmospheric $\mathrm{CO}_{2}$ uptake increase of $0.37 \mathrm{~mol} \mathrm{C} \mathrm{m}^{-2} \mathrm{y}^{-1}$ with respect to 1991 is simulated over the 1991-2002 period (Fig. 6a). Predicted annual $\mathrm{CO}_{2}$ sinks range between $-4.2(1991)$ and $-4.8 \mathrm{~mol} \mathrm{C} \mathrm{m} \mathrm{m}^{-2} \mathrm{y}^{-1}$ with the largest values in 1993, 1994 and 2000 (Fig. 6a). The mean yearly increment is small $(0.1$ mol C m $\mathrm{m}^{-1}$ ) reflecting the effect of ocean physico-chemical conditions (Alkalinity, DIC, temperature) on the annual $\mathrm{CO}_{2}$ sink. This impact can be appraised by comparing current predictions with those obtained by keeping the atmospheric $\mathrm{CO}_{2}$ constant at the concentration level of 1991 (Fig. 6a). From this comparison, we estimated that the only meteorological forcing could modulate the increment of increased atmospheric $\mathrm{CO}_{2}$ uptake by $\pm 10 \%$.

At the KERFIX location, an average increased $\mathrm{CO}_{2}$ uptake by the upper ocean of $0.27 \mathrm{~mol} \mathrm{C} \mathrm{m}^{-2} \mathrm{y}^{-1}$ with respect to nominal year 1993 is simulated over the 1993-2002 period (Fig. 6b). Actually the highest atmospheric sink $\mathrm{CO}_{2}$ is predicted in 2001, reaching $-0.9 \mathrm{~mol} \mathrm{~m}^{-2} \mathrm{y}^{-1}$, i.e. about three times its value in 1994 (Fig. 6b).

Interestingly, our predicted $\mathrm{CO}_{2}$ flux of -0.68 mol $\mathrm{C} \mathrm{m}^{-2} \mathrm{y}^{-1}$ is very close to that estimated by the semi-prognostic model $\left(-0.71 \mathrm{~mol} \mathrm{C} \mathrm{m} \mathrm{C}^{-2}\right)$ of Jabaud-Jan et al. (2004) and similarly attributed to an increased diatom production (not shown). The effect of the oceanic conditions on the annual $\mathrm{CO}_{2}$ is appraised by comparing current predictions with those obtained by keeping constant the atmospheric $\mathrm{CO}_{2}$ of 1993 (Fig. 6b). This comparison clearly suggests that the only meteorological forcing is modulating the increment of increased atmospheric $\mathrm{CO}_{2}$ uptake by $\pm 30 \%$. However, and in contrast with NABE (Fig. 6a), our simulations at KERFIX clearly suggest that, after 1997, the effect of increased atmospheric $\mathrm{CO}_{2}$ has a larger impact on the predicted $\mathrm{CO}_{2}$ sink than only ocean conditions (Fig. 6b).

The largest interannual fluctuations of air-sea $\mathrm{CO}_{2}$ fluxes were obtained at the AESOPS location with predicted values ranging between - 1.36 (1997) and -0.2 (2001) mol C m $\mathrm{C}^{-1}$ (Fig. 6c). These fluctuations are clearly driven by the ice-covered conditions (shown from the comparison with model runs at constant $\mathrm{pCO}_{2}$ of 1991; Fig. 6c) which determine the physical structure of the water column and hence the light conditions, the iron concentration and the responding dominant phytoplankter (Fig. 5c). 


\section{Discussion and conclusion}

\subsection{Overall performance of upgraded SWAMCO: conditions that determine phytoplankton successions}

Evaluation of 1D SWAMCO-4 crossed application in the different JGOFS sites (NABE, KERFIX, AESOPS) as well as model sensitivity runs allowed us to identify important conditions prevailing for phytoplankton species dominance in the global ocean but also revealed important gaps that deserve further experimentation:

In the absence of other limitation (light and/or nutrients including iron) the taxon-specific temperature adaptation is critical. The commonly used formulation of Eppley (1972) for temperature-dependence of phytoplankton growth in the global ocean should not be used for temperatures higher than $20^{\circ} \mathrm{C}$. Nor is temperature adaptation competitive for coccolithophorids. Low temperatures seem to favour Phaeocystis colonies over diatoms at temperatures lower than $4^{\circ} \mathrm{C}$, but this should be further supported by more targeted experiments. The success of Phaeocystis colonies over diatoms in the marginal ice zone of the Ross Sea (AESOPS) is, however, mainly explained by iron sequestration within the Phaeocystis matrix which rapidly deprives other phytoplankters of DFe. The assumed ability of colony cells to use the colony matrix iron-bound for cell growth is critical and determines the height reached by the Phaeocystis bloom. Additional process-level biogeochemical studies are needed to improve parameterisation of the process of $\mathrm{Fe}$ complexation by the Phaeocystis matrix as well as the subsequent uptake by colony cells.

Model runs in the marginal ice zone of the Ross Sea (AESOPS) also suggest that atmospheric Fe deposition is an important source of iron in sea-ice associated systems due to the accumulation of atmospheric dust deposit during the ice-covered period and its sudden release in stratified surface water at the time of ice melting. As suggested by SWAMCO-4 predictions in the Southern Ross Sea, this source of iron (from above) is necessary to explain the observed elevated Phaeocystis-dominated blooms in spring. Iron accumulation in snow and sea ice has occasionally been well measured (De Baar and De Jong, 2001) but has never been systemati- cally explored. Considering the important atmospheric $\mathrm{CO}_{2}$ sink associated with Phaeocystis blooms as predicted by SWAMCO-4, further field measurements are urgently needed to assess the origin, importance and bioavailability of sea-ice associated iron.

SWAMCO-4 crossed applications at the different JGOFS sites also confirm that, as already suggested by laboratory studies (Timmermans et al., 2001 and $\mathrm{ms}$ in prep.), two groups of diatoms have to be considered for the global oceanic Si cycle. These are, respectively, the high- and low-silicified micro- and nano-sized diatoms characterised by, respectively, elevated and low iron kinetics parameters.

Finally, although SWAMCO-4 was able to reproduce the observed field cell density in NABE, we have to admit that current SWAMCO-4 scenarios failed to resolve conditions that determine the success of coccolithophorids. Field experiments suggest that these algae, being able to use organic $\mathrm{P}$ and $\mathrm{N}$, are favoured under low ambient phosphate and nitrate. Conditions of extremely low phosphate are, however, not yet properly simulated by our model.

\subsection{Physical and biological mechanisms driving sea- to-air exchange of $\mathrm{CO}_{2}$}

SWAMCO-4 sensitivity runs concluded that thermodynamical conditions drive primarily the sea-to-air exchange of $\mathrm{CO}_{2}$, but biological processes are modulating this effect during the growing season. This is particularly sensitive in the southern latitudes where, according to our model, diatom-(KERFIX) or Phaeocystis-(AESOPS) associated biological processes are responsible for the predicted annual carbon sink. On the contrary, coccolithophorids are predicted to repress the carbon uptake, even when present at low cell density.

\section{Acknowledgements}

This modelling work is part of the European Union IRONAGES project funded under contract $\mathrm{N}^{\circ}$ ENV4-CT97-0472 by the Key Action Global Change of the Environment and Sustainable Development Programme of the European Commission. Support 
was also given by the Belgian federal research projects BELCANTO (contract $\mathrm{N}^{\circ} \mathrm{EV} / 11 / 7 \mathrm{~B}$ ) and AMORE (contract $\mathrm{N}^{\circ}$ EV-ENZ-05) as well as the $\mathrm{ARC}$ project SIBCLIM funded by the Belgian French Community. H. Goosse is research associate with the Belgian National Fund for Scientific Research. We thank Hein de Baar, the project leader of IRONAGES, for his continuous scientific support, as well as Marcel Veldhuis and one anonymous reviewer for their constructive comments on the draft manuscript.

\section{References}

Anning, T., Nimer, N., Merrett, M.J., Brownlee, C., 1996. Costs and benefits of calcification in coccolithophorids. J. Mar. Syst. 9, $45-56$.

Arrigo, K.R., DiTullio, G.R., Dunbar, R.B., Robinson, D.H., VanWoert, M., Worthen, D.L., Lizotte, M.P., 2000. Phytoplankton taxonomic variability in nutrient utilization and primary production in the Ross Sea. J. Geophys. Res. 105, 8827-8845.

Aumont, O., Belviso, S., Monfray, P., 2002. Dimethylsulfoniopropionate (DMSP) and dimethylsulphide (DMS) sea surface distributions simulated from a global three-dimensional ocean carbon cycle model. J. Geophys. Res. C 107, 148-227.

Balch, W.M., Kilpatrick, K.A., Holligan, P.M., 1993. Coccolith formation and detachment by Emiliania huxleyi (Prymnesiophyceae). J. Phycol. 29, 566-575.

Berliand, M.E., Strokina, T.G., 1980. Global Distribution of the Total Amount of Clouds. Hydrometeorological, Leningrad, Russia. 71 pp. (in Russian).

Bianchi, M., Feliatra, F., Tréguer, P., Vincendeau, M.A., Morvan, J., 1997. Nitrification rates, ammonium and nitrate distribution in upper layers of the water column and in sediments of the Indian sector of the Southern Ocean. Deep-Sea Res. II 44, 1017-1032.

Boyd, P.W., Abraham, E.R., 2001. Iron-mediated changes in phytoplankton photosynthetic competence during SOIREE. Deep-Sea Res. II 48, 2529-2550.

Buma, A.G., De Baar, H., Nolting, R.F., Van Bennekom, A.J., 1991. Metal enrichment experiments in the Weddell Sea: effects of $\mathrm{Fe}$ and $\mathrm{Mn}$ on various plankton communities. Limnol. Oceanogr. $36,1865-1878$.

Coale, K., Wang, X., Tannera, S., Johnson, K., 2003. Phytoplankton growth and biological response to iron and zinc addition in the Ross Sea and Antarctic Circumpolar Current along $170^{\circ} \mathrm{W}$. Deep-Sea Res. II 50, 635-653.

Conway, T.J., Tans, P.P., Waterman, L.S., Thoning, K.W., Kitzis, D.R., Masarie, K.A., Zhang, N., 1994. Evidence for inter-annual variability of the carbon cycle from the National Oceanic and Atmospheric Administration/Climate Monitoring and Diagnostics Laboratory Global Air sampling Network. J. Geophys. Res. 99 (D11), 22831-22855.
De Baar, H.J.W., Boyd, P.W., 1999. The role of iron in plankton ecology and carbon dioxide transfer of the Global Oceans. In: Hanson, R.B., Ducklow, H.W., Filed, J.G. (Eds.), The Dynamic Ocean Carbon Cycle: A Midterm Synthesis of the Joint Global Ocean Flux Study, International Geosphere Biosphere Book Series. Cambridge University Press, Cambridge, pp. 61-140.

De Baar, H.J.W., De Jong, J.T.M., 2001. Distributions, sources and sinks of iron in seawater. In: Turner, D.R., Hunter, K.A. (Eds.), The Biogeochemistry of Seawater. IUPAC Series on Analytical and Physical Chemistry of Environmental Systems. John Wiley and Sons, Chichester, pp. 125-234.

De Baar, H.J.W., De Jong, J.T.M., Bakker, D.C.E., Veth, C., Bathmann, U.W., Löscher, B.M., 1995. Importance of iron for plankton blooms and carbon dioxide drawdown in the Southern Ocean. Nature 373, 412-415.

Engel, E., Thoms, S., Riebesell, U., Rochelle-Newall, E., Zondervan, I., 2004. Polysaccharide aggregation as a potential sink of marine dissolved organic carbon. Nature 428, 929-932.

Eppley, R.W., 1972. Temperature and phytoplankton growth in the ocean. Fish. Bull. 70, 1063-1085.

Fernandez, E., Boyd, P., Holligan, P.M., Harbour, D.S., 1993. Production of organic and inorganic carbon within a large-scale coccolithophore bloom in the northeast Atlantic Ocean. Mar. Ecol. Prog. Ser. 97, 271-285.

Fiala, M., Semeneh, M., Oriol, L., 1998a. Size-fractionated phytoplankton biomass and species composition in the Indian sector of the Southern Ocean during austral summer. J. Mar. Syst. 17, 179-194.

Fiala, M., Kopczynska, E.E., Jeandel, C., Oriol, L., Vetion, G., 1998b. Seasonal and interannual variability of size-fractionated phytoplankton biomass and community structure at station KERFIX, off the Kerguelen Islands, Antarctica. J. Plankton Res. 20, $1341-1356$.

Fichefet, T., Gaspar, P., 1988. A model study of upper ocean-sea ice interactions. J. Phys. Oceanogr. 18, 181-195.

Goosse, H., Deleersnijder, E., Fichefet, T., England, M.H., 1999. Sensitivity of a global coupled ocean-sea ice model to the parameterization of vertical mixing. J. Geophys. Res. 104 (C6), $13681-13695$.

Goosse, H., Campin, J.M., Deleersnijder, E., Fichefet T., Mathieu, P.P., Morales Maqueda, M.A., Tartinville, B., 2000. Description of the CLIO model version 3.0. Scientific Report 2000/3, Institut d'Astronomie et de Géophysique G. Lemaître, Louvainla-Neuve, Belgium, 49 pp. http://www.astr.ucl.ac.be/tools/ clio.html.

Greene, R.M., Geider, R.J., Falkowski, P.G., 1991. Effect of iron limitation on photosynthesis in a marine diatom. Limnol. Oceanogr. 36, 1772-1782.

Häkkinen, S., Mellor, G.L., 1990. One hundred years of Arctic ice cover variations as simulated by a one-dimensional, ice-ocean model. J. Geophys. Res. 95, 15959-15969.

Hannon, E., Boyd, P.W., Silvoso, M., Lancelot, C., 2001. Modelling the bloom evolution and carbon flows during SOIREE: implications for future in situ iron-experiments in the Southern Ocean. Deep-Sea Res. II 48, 2745-2773.

Holligan, P.M., Fernandez, E., Aiken, J., Balch, W.M., Boyd, P., Burkill, P.H., Finch, M., Groom, S.B., Malin, G., Muller, K., 
Purdie, D.A., Robinson, C., Trees, C.C., Turner, S.M., Van der Wal, P., 1993. A biogeochemical study of the coccolithophore, Emiliania huxleyi, in the North Atlantic. Global Biogeochem. Cycles 7, 879-900.

Jabaud-Jan, A., Metzl, N., Brunet, C., Poisson, A., Schauer, B., 2004. Variability of the Carbon Dioxide System in the Southern Indian Ocean $\left(20^{\circ} \mathrm{S}-60^{\circ} \mathrm{S}\right)$ : the impact of a warm anomaly in austral summer 1998. Global Biogeochem. Cycles 18, doi:10.1029/2003GB002017.

Jackson, G.A., 1990. A model of the formation of marine algal flocs by physical aggregation processes. Deep-Sea Res. 37, 1197-1211.

Kalnay, E., et al., 1996. The NCEP/NCAR 40-year reanalysis project. B. Am. Meteorol. Soc. 77, 437-471.

Kantha, L.H., Clayson, C.A., 1994. An improved mixed layer model for geophysical applications. J. Geophys. Res. 99, 25235-25266.

Kriest, I., Evans, G.T., 1999. Representing phytoplankton aggregates in biogeochemical models. Deep-Sea Res. I 46, $1841-1859$.

Kriest, I., Evans, G.T., 2000. A vertically resolved model for phytoplankton aggregation. P. Indian AS-Earth 109, 453-469.

Lancelot, C., Rousseau, V., Billen, G., Van Eeckhout, D.V., 1997. Coastal eutrophication of the Southern Bight of the North Sea: assessment and modelling. In: Ozsoy, E., Mikaelyan, A. (Eds.), Sensitivity to Change: Black Sea, Baltic Sea and North Sea. NATO-ASI. Kluwer Academic Publishers, Dordrecht, pp. 437-454.

Lancelot, C., Keller, M.D., Rousseau, V., Smith, W.O., Mathot, S., 1998. Autecology of the marine haptophyte Phaeocystis sp. In: Anderson, D.M., Cembella, A.D., Hallagraeff, G.M. (Eds.), Physiological Ecology of Harmful Algal Blooms. SpringerVerlag, Berlin, pp. 209-224.

Lancelot, C., Hannon, E., Becquevort, S., Veth, C., De Baar, H.J.W., 2000. Modelling phytoplankton blooms and carbon export in the Southern Ocean: dominant controls by light and iron in the Atlantic sector in Austral spring 1992. Deep-Sea Res. I 47, 1621-1662.

Landry, M.R., Brown, S.L., Selph, K.E., Bidigare, R.R., Johnson, Z., Sheridan, C., Christensen, S., Twining, B., Cassar, N., 2002. Biomass, growth and grazing responses in the SOFeX IronFertilized Patch at $66^{\circ} \mathrm{S}$. Amer. Geophys. Un. Fall Meeting, San Francisco, CA.

La Roche, J., Breitbarth, E., 2005. Importance of the diazotrophs as a source of new nitrogen in the ocean. J. Sea Res. 53, 67-91 (this issue).

Lefevre, N., Watson, A.J., 1999. Modelling the geochemical cycle of iron in the oceans and its impact on atmospheric $\mathrm{CO}_{2}$ concentrations. Global Biogeochem. Cycles 13, 727-736.

Longhurst, A., 1998. Ecological Geography of the Sea. Academic Press, San Diego, 398 pp.

Martin, J.H., 1990. Glacial-interglacial $\mathrm{CO}_{2}$ change: the iron hypothesis. Paleoceanography $5,1-13$.

Martin, J.H., Gordon, R.M., Fitzwater, S.E., 1990. Iron in Antarctic waters. Nature $345,156-158$.

Mellor, G.L., Yamada, T., 1982. Development of a turbulence closure model for geophysical fluid problems. Rev. Geophys. Space GE 20, 851-875.
Moore, J.K., Doney, S.C., Kleypas, J.A., Glover, D.M., Fung, I.Y., 2002. An intermediate complexity marine ecosystem model for the global domain. Deep-Sea Res. II 49, 403-462.

Muggli, D.L., Lecourt, M., Harrison, P.J., 1996. Effects of iron and nitrogen source on the sinking rate, physiology and metal composition of an oceanic diatom from the subarctic Pacific. Mar. Ecol. Prog. Ser. 132, 215-227.

Olson, R.J., 1981. ${ }^{15}$ Ntracer studies of the primary nitrite maximum. J. Mar. Res. 39, 203-226.

Paasche, E., 2002. A review of the coccolithophorid Emiliana huxleyi (Prymnesiophyceae), with particular reference to growth, coccolith formation, and calcification-photosynthesis interactions. Phycologia 40, 503-529.

Passow, U., 2002. Transparent exopolymer particles (TEP) in aquatic environments. Prog. Oceanogr. 55, 287-333.

Pondaven, P., Fravalo, C., Ruiz-Pino, D., Tréguer, P., Quéguiner, B., Jeandel, C., 1998. Modelling the silica pump in the Permanent Open Ocean Zone of the Southern Ocean. J. Mar. Syst. 17, $587-619$.

Rousseau, V., Vaulot, D., Casotti, R., Cariou, V., Lenz, J., Gunkel, J., Baumann, M., 1994. The life cycle of Phaeocystis (Prymnesiophyceae): evidence and hypotheses. J. Mar. Syst. 5, 23-39.

Sarthou, G., Timmermans, K.R., Blain, S., Tréguer, P., 2005. Growth physiology and fate of diatoms in the ocean: a review. J. Sea Res. $53,25-42$ (this issue).

Schlitzer, R., 2002. Carbon export fluxes in the Southern Ocean: results from inverse modeling and comparison with satellitebased estimates. Deep-Sea Res. II 49, 1623-1644.

Schoemann, V., Becquevort, S., Stefels, J., Rousseau, V., Lancelot, C., 2005. Phaeocystis blooms in the global ocean and their controlling mechanisms: a review. J. Sea Res. 53, 43-66 (this issue).

Sedwick, P., Di Tullio, G., 1997. Regulation of algal blooms in Antarctic shelf waters by the release of iron from melting sea ice. Geophys. Res. Lett. 24, 2515-2518.

Smith Jr., W.O., Dennett, M.R., Mathot, S., Caron, D.A., 2003. The temporal dynamics of the flagellated and colonial stages of Phaeocystis Antarctica in the Ross Sea. Deep-Sea Res. II 50, $605-617$.

Takahashi, T., Sutherland, S.C., Sweeney, C., Poisson, A., Metzl, N., et al., 2002. Global sea-Air $\mathrm{CO}_{2}$ flux based on climatological surface ocean $\mathrm{pCO}_{2}$, and seasonal biological and temperature effect. Deep-Sea Res. II 49, 1601-1622.

Timmermans, K.R., Gerringa, L.J.A., De Baar, H.J.W., Van der Wagt, B., Veldhuis, M.J.W., De Jong, J.T.M., Croot, P.L., 2001. Growth rates of large and small Southern Ocean diatoms in relation to availibility of iron in natural seawater. Limnol. Oceanogr. 46, 260-266.

Trenberth, K.E., Olson, J.G., Large, W.G., 1989. A Global Ocean Wind Stress Climatology Based on the ECMWF Analyses, NCAR/TN-338+STR. National Center for Atmospheric Research, Boulder. (93 pp.).

Tyrrell, T., Taylor, A.H., 1996. A modelling study of Emiliania huxleyi in the NE Atlantic. J. Mar. Syst. 9, 83-112.

Van der Wal, P., De Jong, E.W., Westbroek, P., De Bruijn, W.C., Mulder-Stapel, A.A., 1983. Ultrastructural polysaccharide local- 
ization in calcifying and naked cells of the coccolithophorid Emiliania huxleyi. Protoplasma 118, 157-168.

Veldhuis, M.J.W., Timmermans, K.R., Croot, P., Van der Wagt, B., 2005. Picophytoplankton; a comparative study of their biochemical composition and photosynthetic properties. J. Sea Res. $53,7-24$ (this issue).
Xie, P., Arkin, P.A., 1996. Analyses of global monthly precipitation using gauge observations, satellite estimates and numerical model predictions. J. Climate 9, 840-858.

Young, J.R., 1994. Variation in Emiliania huxleyi coccolith morphology in samples from the Norwegian EHUX experiment, 1992. Sarsia 79, 417-425. 